\title{
Leflunomide inhibits proliferation and tumorigenesis of oral squamous cell carcinoma
}

\author{
AISHU REN ${ }^{1,2^{*}}$, GANG FU $^{1,2^{*}}, \mathrm{YU}^{\mathrm{QIU}}{ }^{2}$ and HONGJUAN CUI ${ }^{1}$ \\ ${ }^{1}$ State Key Laboratory of Silkworm Genome Biology, Southwest University, Chongqing 400716; \\ ${ }^{2}$ Chongqing Key Laboratory for Oral Diseases and Biomedical Sciences, Affiliated Hospital \\ of Stomatology, Chongqing Medical University, Chongqing 401147, P.R. China
}

Received December 21, 2016; Accepted July 4, 2017

DOI: $10.3892 / \mathrm{mmr} .2017 .7755$

\begin{abstract}
Oral squamous cell carcinoma (OSCC) is the most prevalent pathological cancer occurring in the head and neck area. Progress has previously been made regarding treatment strategies of OSCC, however the 5-year survival rate of these patients is only $50 \%$. The present study examined if leflunomide (LEF), a drug primarily used for the treatment of rheumatoid arthritis, exhibited antitumor effects in OSCC. The results demonstrated that LEF inhibited cell proliferation and blocked the cell cycle at the S phase in OSCC cells, with upregulation of cyclin A protein expression. LEF reduced the expression of dihydroorotate dehydrogenase, which is an essential enzyme in the de novo pyrimidine biosynthetic pathway. LEF additionally inhibited colony formation in soft agar and reduced tumor growth in a xenograft model. The results suggested that LEF may act as a potential therapeutic agent in the treatment of OSCC in the future.
\end{abstract}

\section{Introduction}

Head and neck cancer is the sixth most common cancer worldwide, which affect 650,000 people and cause 350,000 deaths per year (1). Oral squamous cell carcinoma (OSCC) is the most common type of head and neck cancer, which accounts for more than $80 \%$ of all forms of head and neck cancer (2). In spite of some advances in the treatment of OSCC, the five-year survival rate of these patients is only $50 \%$ and has not improved in the past three decades (3). The poor prognosis is due to poor response to current therapy methods and high

Correspondence to: Professor Hongjuan Cui, State Key Laboratory of Silkworm Genome Biology, Southwest University, 2 Tiansheng Road, Chongqing 400716, P.R. China

E-mail: hongjuan.cui@gmail.com; hcui@swu.edu.cn

*Contributed equally

Key words: leflunomide, oral squamous cell carcinoma, proliferation, cell cycle, dihydroorotate dehydrogenase, tumorigenicity recurrence rates (4). Therefore, it is necessary to identify additional therapeutic options for OSCC.

Leflunomide (LEF) is an anti-inflammatory and immunomodulatory drug which was introduced and licensed for the treatment of rheumatoid arthritis (RA) in 1998 (5). Besides that, some other treatment potential of LEF has been reported. LEF has been used in other autoimmune diseases, like Psoriatic Arthritis, Wegener granulomatosis, Sarcoidosis and others (6). LEF also been used as antiviral drug in solid organ transplantation for polyomavirus type BK or cytomegalovirus infection (5). In addition, some reports showed that LEF had anti-proliferation effect in some malignant tumors including glioma $(7,8)$, leukemia $(9,10)$, melanoma (11), and neuroblastoma (12). These reports provided evidence that LEF might be used as a novel drug for antitumoral treatment. However, the effect of LEF on the growth of OSCC is not clear.

In this study, we showed that LEF inhibited cell proliferation and blocked cell cycle in S phase in OSCC. We also found that LEF inhibited colony formation in soft agar and reduced tumor growth in a xenograft model. The result suggested that LEF might be an optional agent for the treatment of OSCC.

\section{Materials and methods}

Cell culture. Human OSCC cell lines Tca8113 and KB were purchased from Shanghai Cell Bank, Chinese Academy of Science. Both cells were grown in RPMI-1640 supplemented with $10 \%$ fetal bovine serum (FBS) and $1 \%$ antibiotics penicillin and streptomycin (P/S). The growth media, FBS and antibiotics were purchased from Gibco. The cells were cultured at $37^{\circ} \mathrm{C}$ in a $5 \% \mathrm{CO}_{2}$ humidified incubators.

Cell growth assay. Leflunomide was dissolved in dimethyl sulfoxide (DMSO) (both from Sigma) as $200 \mathrm{mM}$ stock solutions. Tca8113 and KB cells were seed in 6-well plate at 20,000 cells/well for overnight. Then the cells were treated with $100 \mu \mathrm{M}$ LEF or DMSO for $72 \mathrm{~h}$. Micrographs of cell morphology were taken by an inverted microscopy (Olympus). Cells were collected and calculated by trypan blue staining.

Cell viability was further determined using MTT assay. Cells were seed in 96-well plate at 1,000 cells/well for overnight. Then the cells were treated with LEF at $25,50,100$ or $200 \mu \mathrm{M}$. After indicated time period, $20 \mu \mathrm{l}$ MTT (5 mg/ml; 
Sigma) was added to each well and incubated at $37^{\circ} \mathrm{C}$ for $4 \mathrm{~h}$. Then the supernatant was removed and $200 \mu 1$ DMSO was poured to each well to dissolve the cell pellets. After shaking for $15 \mathrm{~min}$, the absorbance was measured at a wavelength of $570 \mathrm{~nm}$.

Cell cycle assay. Cells were plated in $10-\mathrm{cm}$ plates and treated with $100 \mu \mathrm{M}$ LEF or DMSO. After $72 \mathrm{~h}$ of treatment, cells were collected and fixed with $70 \%$ ethanol, resuspended in $200 \mu \mathrm{l}$ PBS and stained with $1 \mu \mathrm{l}$ propidium iodide (PI, $5 \mathrm{mg} / \mathrm{ml}$ ) for $1 \mathrm{~h}$, and analyzed by flow cytometry with CellQuest analysis software (BD Biosciences).

Apoptosis assay. Cells were plated in $10-\mathrm{cm}$ plates and treated with $100 \mu \mathrm{M}$ LEF or DMSO. After $72 \mathrm{~h}$ of treatment, cells were collected and resuspended in $100 \mu \mathrm{l}$ binding buffer, incubated with $2.5 \mu \mathrm{l}$ FITC-Annexin V and $5 \mu \mathrm{l} \mathrm{PI}(50 \mu \mathrm{g} / \mathrm{ml})$ for $15 \mathrm{~min}$, and analysed by flow cytometry with CellQuest analysis software.

Western blot assay. Cells were plated in $10-\mathrm{cm}$ plates and treated with $100 \mu \mathrm{M}$ LEF or DMSO. After 48 or $72 \mathrm{~h}$ of treatment, cells were collected and proteins were extracted with RIPA lysis buffer and PMSF (Beyotime). Protein concentrations were determined with enhanced BCA protein assay kit (Beyotime). Seventy micrograms of proteins were separated in $10 \%$ SDS-PAGE and transferred to PVDF membranes. After blocked with $5 \%$ nonfat milk for $2 \mathrm{~h}$, the membrane was washed in TBST and incubated with primary antibody for overnight. Then the membrane was washed in TBST and incubated with horseradish peroxidase (HRP)-labeled secondary antibody for $2 \mathrm{~h}$. The signal was visualized by the ECL reagent (Beyotime) and captured by western blotting detection instruments (Clinx Science). The primary antibodies mouse anti-CDK2 (sc-6248, 1:200), mouse anti-dihydroorotate dehydrogenase (DHODH, sc-166377, 1:200) and rabbit anti-CCNA (sc-751, 1:200) were purchased from Santa Cruz Biotechnology. The primary antibody mouse anti-GAPDH (AG019, 1:1,000) was purchased from Beyotime Biotech. The second antibodies including HRP-labeled goat anti-mouse IgG $(\mathrm{H}+\mathrm{L})(\mathrm{A} 0216,1: 5,000)$, and HRP-labeled goat anti-rabbit IgG $(\mathrm{H}+\mathrm{L})(\mathrm{A} 0208,1: 5,000)$ were purchased from Beyotime Biotech.

Soft agar colony formation assay. The lower gel including $0.6 \%$ soft agar (Sigma) and culture media was used as support. The upper gel consisted of $0.3 \%$ soft agar and culture media. The cells were suspended in upper gel, seed in 6-well plates at 1,000 cells/well and treated with $100 \mu \mathrm{M}$ LEF or DMSO. After 20 days of treatment, the micrographs of cell colonies were taken by an inverted microscopy. Then the cells were stained with MTT and pictures were taken using a scanner (Epson).

In vivo tumorigenic assay. Six severe combined immunodeficiency (SCID) mice (4 weeks old) were used and maintained under specific pathogen-free conditions. Tca8113 cells were trypsinized and collected. Cells $\left(1 \times 10^{6}\right)$ were subcutaneously injected in $200 \mu \mathrm{l}$ culture media into the flanks of SCID mice. After 7 days of tumor growth, the mice were administered intraperitoneal injections of LEF $(7.5 \mathrm{mg} / \mathrm{kg})$ or control DMSO once daily for 7 days. Tumor diameter was measured with digital calipers every day, and tumor volume was calculated (volume $=$ length $\mathrm{x}$ width ${ }^{2} \mathrm{x} 0.5236$ ). Mice body weight was monitored every two days. After treatment, the mice were sacrificed by $\mathrm{CO}_{2}$, and tumors were measured and weighed. All animal experiments were pre-approved by the Institutional Animal Care and Use Committee of our university.

Statistical analysis. Each experiment was repeated at least three times. The results were presented as mean $\pm \mathrm{SD}$. The two-tailed Student's t-test was performed for paired samples. $\mathrm{P}<0.05$ was considered statistically significant.

\section{Results}

LEF inhibited cell growth and proliferation in OSCC cells. Two OSCC cell lines Tca8113 and KB were treated with LEF or control DMSO for $72 \mathrm{~h}$. The result showed that LEF at $100 \mu \mathrm{M}$ dramatically inhibited cell growth compared with DMSO-treated control (Fig. 1A). More than 50\% reduction in cell number was observed in both cell lines (Fig. 1B). To further investigate the cytostatic effects of LEF, cell growth curve was determined by MTT assay. The result showed that LEF could inhibit cell growth in a dose and time-dependent manner in both cells (Fig. 1C). LEF at concentration higher than $100 \mu \mathrm{M}$ could lead to dramatically decrease in cell number compared with control, so $100 \mu \mathrm{M}$ LEF was used in following experiments. This dose was consistent with other studies $(12,13)$.

LEF induced cell cycle S phase arrest in OSCC cells. Then we examined whether LEF could affect cell cycle in Tca8113 and KB cells. As shown in Fig. 2A, $100 \mu \mathrm{M}$ LEF dramatically increased cell proportion in $\mathrm{S}$ phase and decreased cell proportion in G0/G1 phase. The percentage of $\mathrm{S}$ phase cells increased from 40.73 to $68.41 \%$ in Tca8113 and from 35.41 to $68.92 \%$ in KB. We further checked the expression of cell cycle regulatory protein related to $\mathrm{S}$ phase arrest. The results showed that the expression of CCNA was obviously upregulated in both Tca8113 and KB cells after LEF treatment, while the expression of CDK2 didn't change (Fig. 2B). Taken together, our results demonstrated that LEF could inhibit OSCC cells growth through regulating the expression of cell cycle protein and inducing $\mathrm{S}$ phase arrest.

LEF induced cell apoptosis in KB cells, not in Tca8113 cells. In order to determine whether LEF induced apoptosis in Tca8113 and KB cells, we performed a flow cytometry assay by FITC Annexin V and PI staining. The results demonstrated that $100 \mu \mathrm{M}$ LEF slightly increased apoptotic cells proportion from 3.91 to $4.39 \%$ in Tca8113 cells after $72 \mathrm{~h}$ treatment. The difference was not significant after statistical analysis. However, LEF treatment obviously increased apoptotic cell proportion from 0.97 to $13.48 \%$ in KB cells (Fig. 3). These results showed that apoptosis was implicated in LEF-induced inhibition of growth in KB cells, but not in Tca8113 cells.

LEF reduced DHODH expression in OSCC cells. DHODH is one of the essential enzymes in the de novo pyrimidine 
A

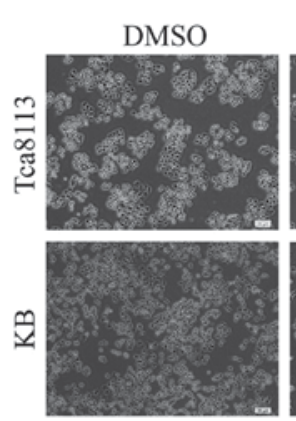

LEF

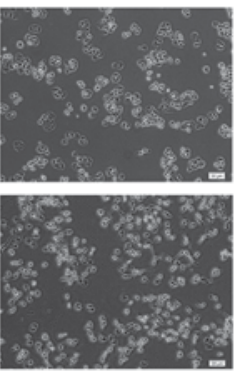

B

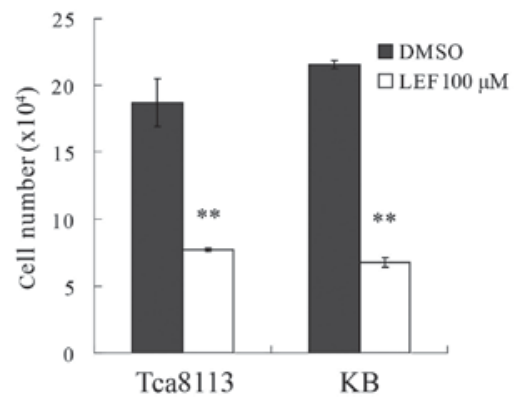

$\mathrm{C}$

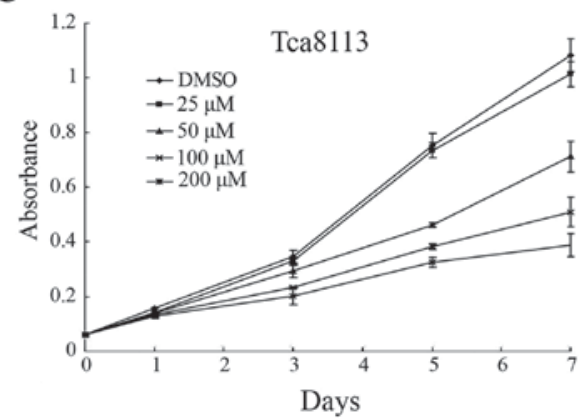

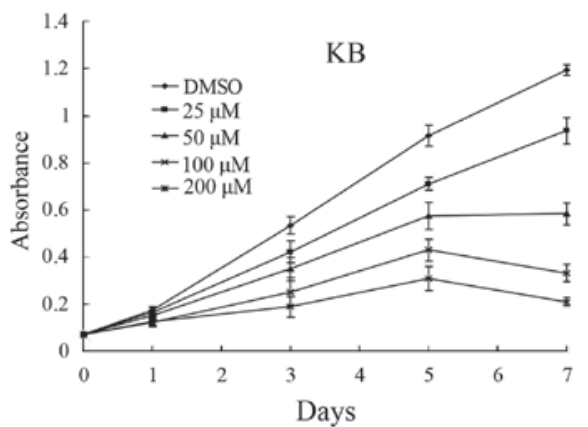

Figure 1. Leflunomide inhibited cell growth and proliferation in OSCC cells (A). Cell morphologic observation of Tca8113 and KB cells after being treated with $100 \mu \mathrm{M}$ leflunomide or DMSO for $72 \mathrm{~h}$ (B). Cell counting of Tca8113 and KB cells after being treated with $100 \mu \mathrm{M}$ leflunomide or DMSO for $72 \mathrm{~h}$. ${ }^{* *} \mathrm{P}<0.01 . \mathrm{N}=3$ (C). Tca8113 and KB cells were treated with leflunomide at 25, 50, 100 or $200 \mu \mathrm{M}$. DMSO was used as a control. Cell growth was tested by MTT assay every 2 days. $\mathrm{N}=3$.

A
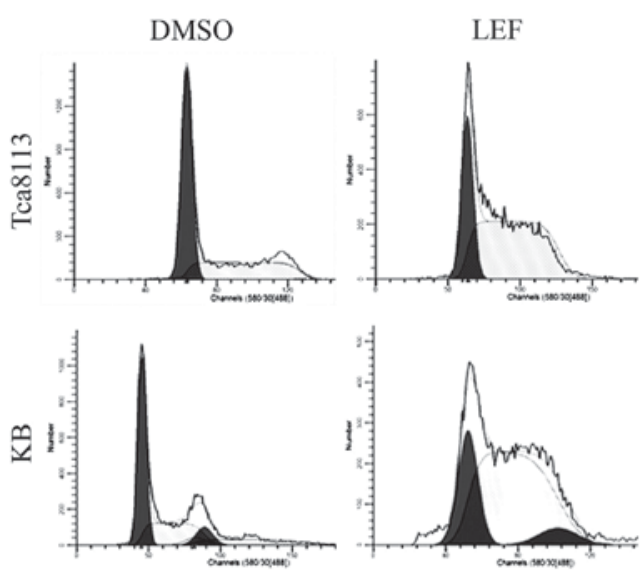

B

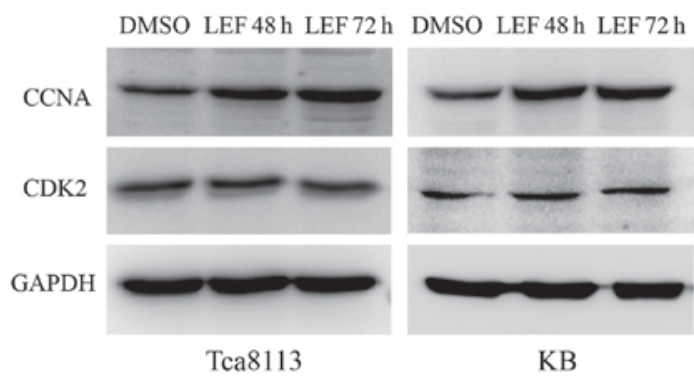

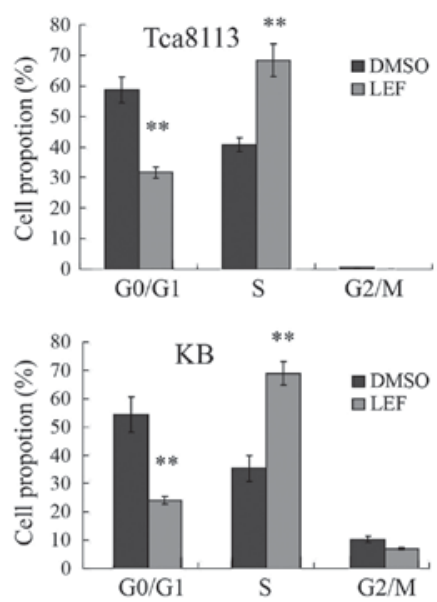

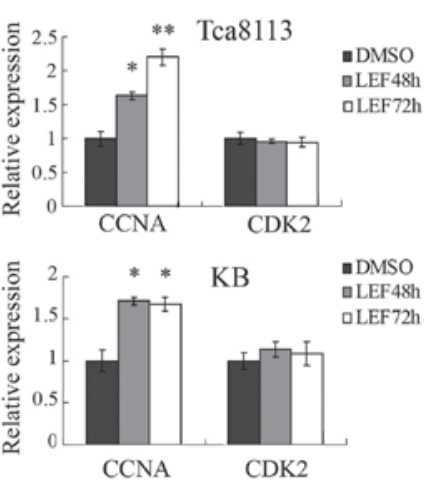

Figure 2. Leflunomide induced cell cycle S phase arrest in OSCC cells (A). After being treated with $100 \mu \mathrm{M}$ leflunomide or DMSO for $72 \mathrm{~h}$, the cell cycle of Tca8113 and KB cells was examined by PI staining. ${ }^{* *} \mathrm{P}<0.01$. N=3 (B). After being treated with $100 \mu \mathrm{M}$ leflunomide for 48 or $72 \mathrm{~h}$, protein expression of CCNA and CDK2 in Tca8113 and KB cells was investigated by western blot assay. DMSO was used as a control. ${ }^{*} \mathrm{P}<0.05,{ }^{* * *} \mathrm{P}<0.01$. $\mathrm{N}=3$. 

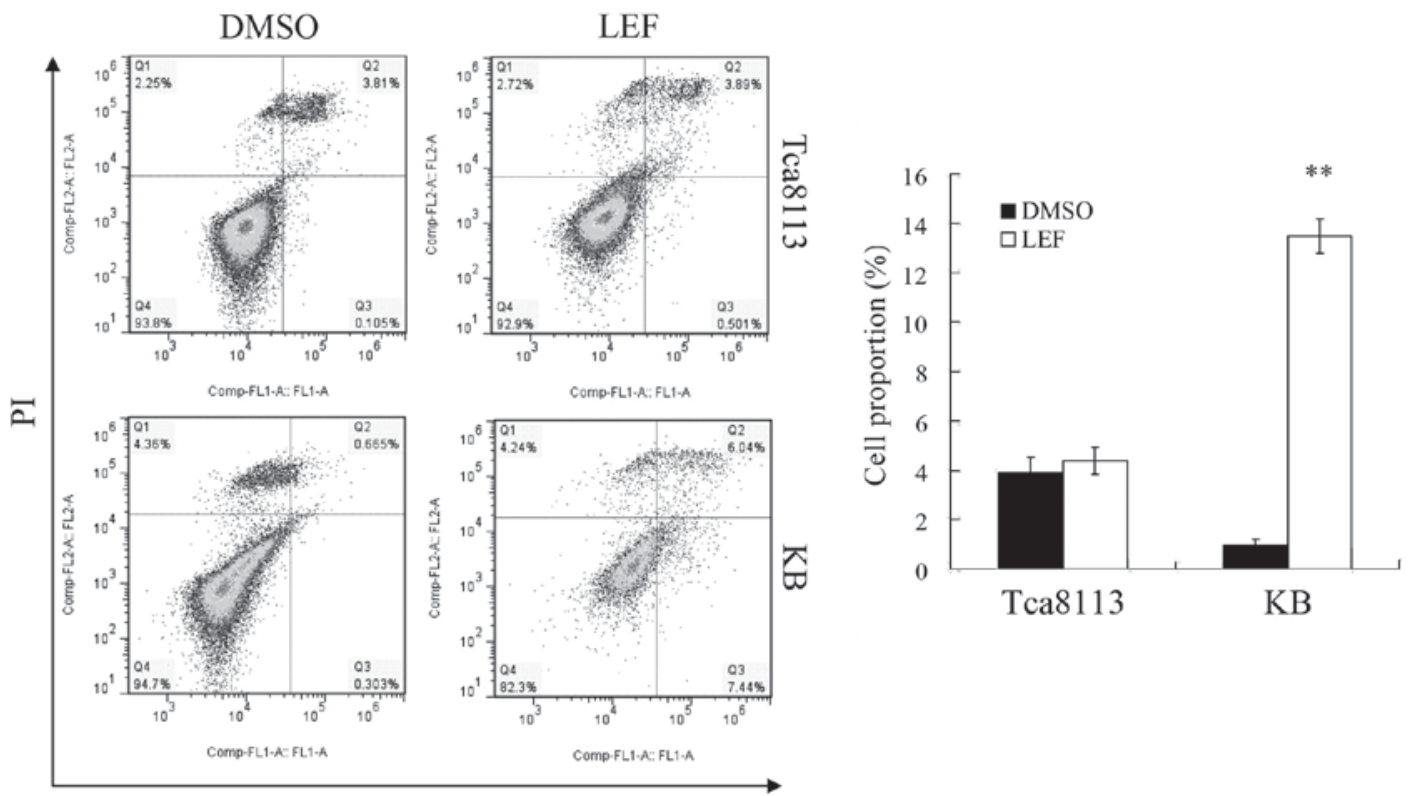

FITC Annexin-V

Figure 3. Leflunomide induced cell apoptosis in KB cells, not in Tca8113 cells. After being treated with $100 \mu \mathrm{M}$ leflunomide or DMSO for $72 \mathrm{~h}$, the cell apoptosis was examined by FITC-Annexin V and PI labeling. ${ }^{* *} \mathrm{P}<0.01 . \mathrm{N}=3$.
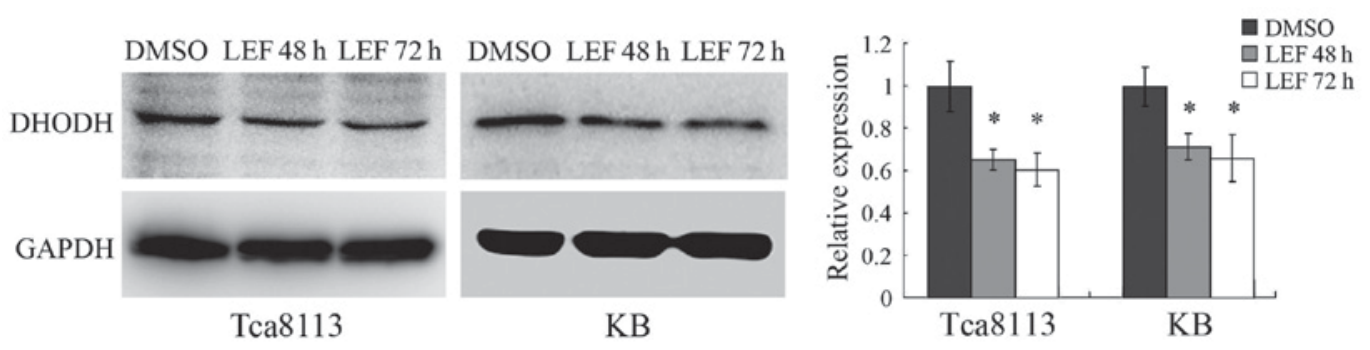

Figure 4. Leflunomide inhibited DHODH expression in OSCC cells. After being treated with $100 \mu \mathrm{M}$ leflunomide for 48 or $72 \mathrm{~h}$, DHODH protein expression of Tca8113 and KB cells was investigated by western blot assay. DMSO was used as a control. ${ }^{*} \mathrm{P}<0.05$. $\mathrm{N}=3$.

biosynthetic pathway. LEF was reported to interfere with the metabolism of pyrimidine nucleotides through directly blocking the activity of DHODH (14,15). Some studies have shown that DHODH inhibition through LEF was effective for treatment of some cancers including melanoma (11) and neuroblastoma (12).

To further explore the pathway by which LEF inhibited cell growth in OSCC cells, we performed western blot assay to detect the protein expression of DHODH after LEF treatment. We found that LEF dramatically reduced DHODH expression in Tca8113 and KB cells after 48 or $72 \mathrm{~h}$ treatment (Fig. 4). The results indicated that downregulation of DHODH expression might be one of the mechanisms implicated in LEF-induced inhibition of growth in OSCC cells.

LEF inhibited soft agar colony formation of OSCC cells. To determine whether LEF inhibits tumorigenic ability of Tca8113 and KB cells in vitro, we performed a soft agar colony formation assay. After 20 days of treatment, $100 \mu \mathrm{M}$ LEF obviously inhibited the volume and number of colonies in both cell lines (Fig. 5A and B). These results suggested that LEF could inhibit anchorage-independent growth and colony formation capacity in OSCC cells.
LEF inhibited tumor growth in mouse xenograph model. We further examined the effect of LEF on OSCC tumor growth in mouse xenograph model. Tca8113 cells were injected into SCID mice subcutaneously. After 7 days of tumor growth, LEF was used for 7 days. The result showed that LEF treatment inhibited tumor growth dramatically (Fig. 6A-C). The tumor volume and weight was decreased by 42.7 and $37.6 \%$ respectively. In addition, the injection of LEF did not affect the animal weight (Fig. 6D) and behaviour. These results suggested that LEF could inhibit OSCC growth in vivo.

\section{Discussion}

In recent years, LEF have been reported to display some antitumoral activity in several kinds of malignant tumors by inhibiting cell growth and proliferation. In this study, we investigated the effect of LEF on OSCC growth in vitro and in vivo. The result showed that LEF obviously reduced OSCC cell growth, colony formation and xenograph tumor growth.

It was reported that LEF could inhibit cell growth by G0/G1 phase cell cycle arrest in multiple myeloma cells (16) and chronic lymphocytic leukemia cells (9) or $\mathrm{S}$ phase cell 
A

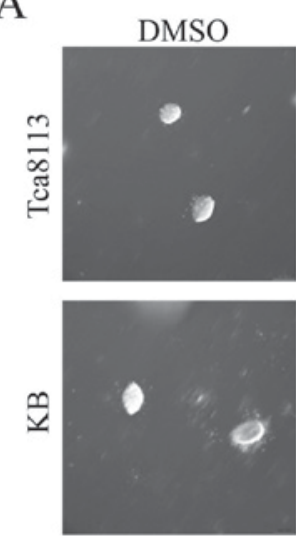

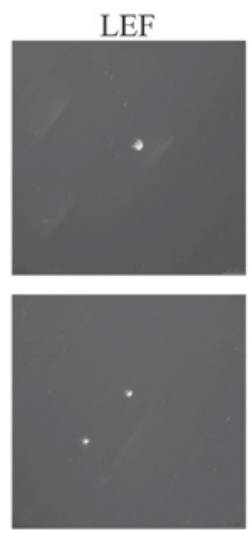

B

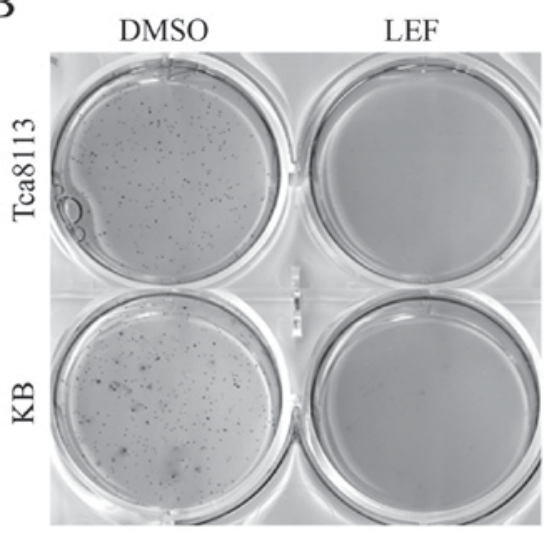

Figure 5. Leflunomide reduced colony formation of OSCC cells in soft agar (A). Tca8113 and KB cells were seed in soft agar in 6-well plates at 1,000 cells/well and treated with $100 \mu \mathrm{M}$ leflunomide or DMSO. After 20 days of treatment, the micrographs of cell colonies were taken by an inverted microscopy (B). The cell colonies of Tca8113 and KB cells were stained with MTT and pictures were taken with a scanner.

A

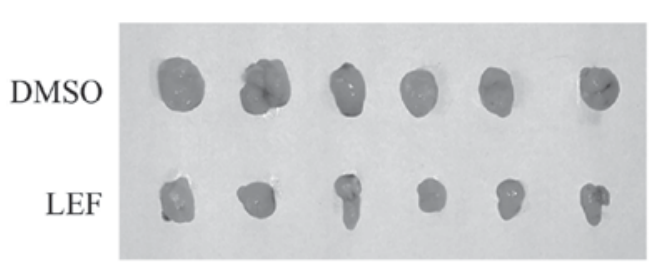

$\mathrm{C}$

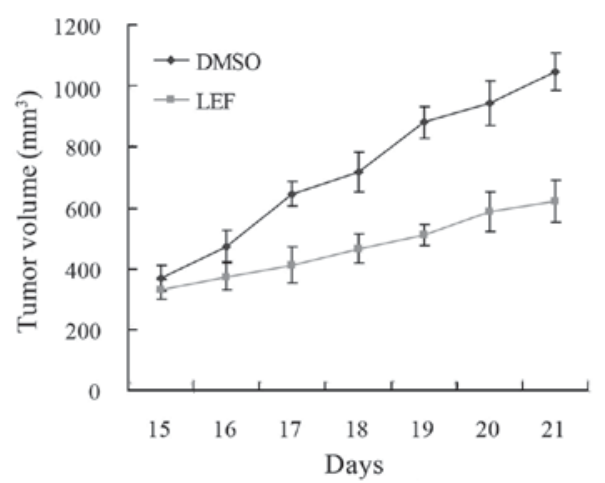

B

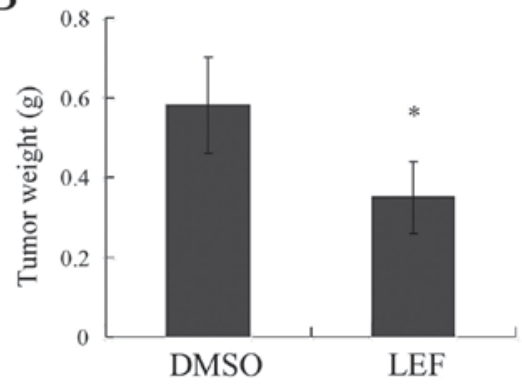

$\mathrm{D}$

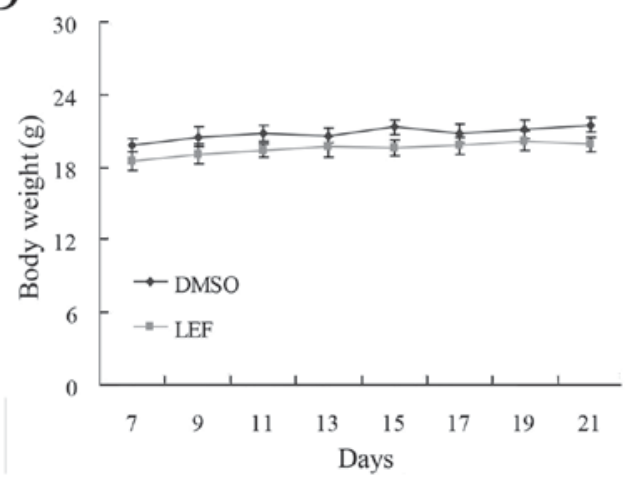

Figure 6. Leflunomide repressed tumor growth in mouse xenograph model (A). The photo of SCID mice xenograft tumor after being treated with leflunomide $\left(7.5 \mathrm{mg} / \mathrm{kg}\right.$ ) or DMSO (B). The xenograft tumor weight after being treated with leflunomide or DMSO. ${ }^{*} \mathrm{P}<0.05 . \mathrm{N}=3(\mathrm{C})$. The xenograft tumor volume after being treated with leflunomide or DMSO. N=3 (D). The SCID mice body weight after being treated with leflunomide or DMSO. N=3.

cycle arrest in neuroblastoma (12) and prostate cancer (17). In this study we confirmed that LEF induced $\mathrm{S}$ phase cell cycle arrest in OSCC cells. The percentage of $\mathrm{S}$ phase cells increased obviously in both Tca8113 and KB cells. Then we examined the expression of cell cycle regulatory protein related to $S$ phase arrest. We found that the expression of CCNA was obviously upregulated in both cells after LEF treatment. Therefore, the inhibition of cell cycle progression might be an important mechanism by which LEF controlled OSCC cells growth.

LEF was also reported to promote apoptosis in a variety of tumor cells $(9,12,16,17)$. In this study we found that LEF induced apoptosis in KB cells, but not in Tca8113 cells. The result suggested that the pro-apoptotic effect of LEF was restricted to certain kinds of OSCC cells. LEF might interfere with different pathways in Tca8113 and KB cells and lead to different apoptosis effect. The similar result was found by Ringshausen et al (9). They found that teriflunomide (an active metabolite of LEF) treatment induced apoptosis in ZAP70-positive chronic lymphocytic leukemia cells, whereas it failed to induce cell death in ZAP70-negative cells. Thus the apoptosis effect of LEF in OSCC cells might depend on different cell kinds.

LEF had been reported to inhibit tumor growth by interfering with the enzymatic activity of DHODH and inhibiting pyrimidine biosynthesis (11), or by inhibiting the tyrosine 
kinase activity of platelet-derived growth factor (PDGF) receptor $(7,18)$ or epidermal growth factor (EGF) receptor $(19)$. The biological activity of LEF was dependent of its active metabolite, A77 1726. Previous studies have demonstrated that A77 1726 was capable of inhibiting the activities of DHODH and tyrosine kinases (20). In this study we found that LEF dramatically reduced DHODH expression in both Tca8113 and KB cells. The results suggested that DHODH pathway might be one of the mechanisms implicated in LEF-induced inhibition of growth in OSCC cells. Whether LEF could inhibit the growth of OSCC cells via inhibiting the activities of tyrosine kinases will be investigated in our next study.

In summary, our study demonstrated that LEF could inhibit cell proliferation and tumor growth of OSCC cells. LEF has been used in clinical treatment of RA for more than ten years. Because of its prominent antitumoral effect in OSCC and its known toxicology and pharmacology in humans and animals, LEF could be an optional candidate for OSCC treatment.

\section{Acknowledgements}

This study was supported by China Postdoctoral Science Foundation (2013M542248) and open project of State Key Laboratory of Silkworm Genome Biology (20120015).

\section{References}

1. Argiris A, Karamouzis MV, Raben D and Ferris RL: Head and neck cancer. Lancet 371: 1695-1709, 2008.

2. Landis SH, Murray T, Bolden S and Wingo PA: Cancer statistics, 1999. CA Cancer J Clin 49: 8-31, 1999.

3. Siegel R, Naishadham D and Jemal A: Cancer statistics, 2012. CA Cancer J Clin 62: 10-29, 2012.

4. Bettendorf O, Piffkò J and Bànkfalvi A: Prognostic and predictive factors in oral squamous cell cancer: Important tools for planning individual therapy? Oral Oncol 40: 110-119, 2004.

5. Teschner S and Burst V: Leflunomide: A drug with a potential beyond rheumatology. Immunotherapy 2: 637-650, 2010.

6. Pinto P and Dougados M: Leflunomide in clinical practice. Acta Reumatol Port 31: 215-224, 2006.

7. Xu X, Shen J, Mall JW, Myers JA, Huang W, Blinder L, Saclarides TJ, Williams JW and Chong AS: In vitro and in vivo antitumor activity of a novel immunomodulatory drug, leflunomide: Mechanisms of action. Biochem Pharmacol 58: 1405-1413, 1999.
8. Strawn LM, Kabbinavar F, Schwartz DP, Mann E, Shawver LK, Slamon DJ and Cherrington JM: Effects of SU101 in combination with cytotoxic agents on the growth of subcutaneous tumor xenografts. Clin Cancer Res 6: 2931-2940, 2000.

9. Ringshausen I, Oelsner M, Bogner C, Peschel C and Decker T: The immunomodulatory drug Leflunomide inhibits cell cycle progression of B-CLL cells. Leukemia 22: 635-638, 2008.

10. Dietrich S, Krämer OH, Hahn E, Schäfer C, Giese T, Hess M, Tretter T, Rieger M, Hüllein J, Zenz T, et al: Leflunomide induces apoptosis in fludarabine-resistant and clinically refractory CLL cells. Clin Cancer Res 18: 417-431, 2012.

11. White RM, Cech J, Ratanasirintrawoot S, Lin CY, Rahl PB, Burke CJ,Langdon E, Tomlinson ML, Mosher J, Kaufman C, et al: DHODH modulates transcriptional elongation in the neural crest and melanoma. Nature 471: 518-522, 2011.

12. Zhu S, Yan X, Xiang Z, Ding HF and Cui H: Leflunomide reduces proliferation and induces apoptosis in neuroblastoma cells in vitro and in vivo. PLoS One 8: e71555, 2013.

13. Alhefdhi A, Burke JF, Redlich A, Kunnimalaiyaan M and Chen H: Leflunomide suppresses growth in human medullary thyroid cancer cells. J Surg Res 185: 212-216, 2013.

14. Greene S, Watanabe K, Braatz-Trulson J and Lou L: Inhibition of dihydroorotate dehydrogenase by the immunosuppressive agent leflunomide. Biochem Pharmacol 50: 861-867, 1995.

15. Bruneau JM, Yea CM, Spinella-Jaegle S, Fudali C, Woodward K, Robson PA, Sautès C, Westwood R, Kuo EA, Williamson RA and Ruuth E: Purification of human dihydro-orotate dehydrogenase and its inhibition by A77 1726, the active metabolite of leflunomide. Biochem J 336: 299-303, 1998.

16. Baumann P, Mandl-Weber S, Völkl A, Adam C, Bumeder I, Oduncu F and Schmidmaier R: Dihydroorotate dehydrogenase inhibitor A771726 (leflunomide) induces apoptosis and diminishes proliferation of multiple myeloma cells. Mol Cancer Ther 8: 366-375, 2009.

17. Hail N Jr, Chen P and Bushman LR: Teriflunomide (leflunomide) promotes cytostatic, antioxidant, and apoptotic effects in transformed prostate epithelial cells: Evidence supporting a role for teriflunomide in prostate cancer chemoprevention. Neoplasia 12: 464-475, 2010.

18. Shawver LK, Schwartz DP, Mann E, Chen H, Tsai J, Chu L, Taylorson L, Longhi M, Meredith S, Germain L, et al: Inhibition of platelet-derived growth factor-mediated signal transduction and tumor growth by $\mathrm{N}$-[4(trifluoromethyl)-phenyl]5-methylisoxazole-4-carboxamide. Clin Cancer Res 3: 1167-1177, 1997.

19. Mattar T, Kochhar K, Bartlett R, Bremer EG and Finnegan A: Inhibition of the epidermal growth factor receptor tyrosine kinase activity by leflunomide. FEBS Lett 334: 161-164, 1993.

20. Xu X, Williams JW, Gong H, Finnegan A and Chong AS: Two activities of the immunosuppressive metabolite of leflunomide, A77 1726. Inhibition of pyrimidine nucleotide synthesis and protein tyrosine phosphorylation. Biochem Pharmacol 52: $527-534,1996$. 